\title{
Research on the Influencing Factors of Green Process Innovation Path of Manufacturing Based on Niche Ecostate-Ecorole
}

\author{
Hongna Tian, Hongyan Yin and Bo Shi \\ Harbin University of Science and Technology, Harbin, 150040, China \\ tianhongna@hrbust.edu.cn
}

\begin{abstract}
In order to explore the influencing factors of green process innovation path of manufacturing, this paper puts forward a concept model of influencing factors of green process innovation path of manufacturing based on the niche ecostate-ecorole theory, studying the influencing factors from three aspects: the ecostate attribute, the ecostate and ecorole interface attribute, and the ecorole attribute. It proposes some hypotheses and tests them by carrying out structural equation model analysis on the basis of large sample data from 29 manufacturing industries in China, and then makes empirical researches on the influencing power of each factor on green process innovation path. The study tells us that the ecostate attribute, the ecostate and ecorole interface attribute and the ecorole attribute of green process innovation have obvious positive influences on green process innovation path of manufacturing. Among which, personnel and funds of scientific and technological activities, tax exemption and reduction to encourage technology development, and the rate of assets contribution have the most significant impact on green process innovation path of manufacturing.
\end{abstract}

Keywords: manufacturing; green process innovation; innovation path; influencing factors of path; niche ecostate-ecorole theory

\section{Introduction}

As an important foundation for economic development, manufacturing has become a leading force in a nation's industries. At the same time of creating abundant wealth for national economy, manufacturing also consumes large amount of limited resources, causing environmental pollution. Green innovation of manufacturing is an inevitable trend for sustainable development of human society. In order to achieve the new manufacturing with high efficiency, energy saving, environmental protection and sustainable development, attention and research on the green innovation of manufacturing, especially the green technology innovation activities must be strengthened. As an integral part of green technology innovation, green process innovation is an effective way to solve the conflict between environmental pollution caused by manufacturing and the rapid development. The so-called green process innovation of manufacturing refers to a series of development and improvement activities in the fields of production process, processing technology, operating method, and production equipment, etc., They are implemented by manufacturing enterprises, which are fulfilled with interaction and information communication among main bodies participating in the green process innovation activities of manufacturing. They are aiming to improve quality, decrease cost, save energy and reduce pollution based on the accurate grasp of market dynamics [1]. Green process innovation is an important way to realize the transformation from traditional manufacturing to modern manufacturing. Design, selection and implementation of green process innovation path have a direct impact on the level of green process innovation. During the course of understanding, exploring, choosing and implementing green process innovation path of manufacturing, we need to correctly identify the influencing factors. 
By exploring and confirming these influencing factors and promoting the development of green process innovation path with target, we can realize a positive cycle of green economy development in manufacturing and ecological environmental protection, and then enhance the green process innovation ability, foster the innovation paths for each manufacturing industry, and lay a solid foundation for manufacturing innovation. It has great significance to improve the level of green innovation of manufacturing in China and promote sustainable development of the society.

The paper is organized as follows. It reviews the literature from the technological innovation path, the influencing factors of innovation path, and the niche ecostate-ecorole theory. It then builds a conceptual model and research hypothesis, explains the various factors influence on the activity of green process innovation of manufacturing from the ecostate attribute, the ecostate and ecorole interface attribute, and the ecorole attribute of green process innovation. Next, the paper makes empirical analysis by using structural equation model, and it determines the degree of influence of various factors on the innovation path. Finally, the paper provides a conclusion and recommendation. It finds that the ecostate attribute, the ecostate and ecorole interface attribute, and the ecorole attribute of green process innovation have significant positive influence to green process innovation path.

\section{Literature Review}

Research on technological innovation path has always attracted the attention of scholars from China and other countries, and they have made abundant achievements in this area. In recent years, scholars have analyzed technological innovation path from macro perspective, meso perspective, and micro perspective.

In the macro perspective, David et. al., (1999) expounded the innovation path of American technology in the 20th-century, such as internal combustion engine industry, chemical industry, electric power and electronics [2]. Chen (2007) illustrated the positive and negative influences of EU standardization externalities on China's technology innovation [3]. Fu and $\mathrm{Gu}$ (2008) improved China's technology innovation from the following paths: investment in research \& development, technological learning ability, self-owned brand creation, integration of technology resources, and the use of external resources [4]. Evgeny and Klochikhin (2012) considered that Russia should establish an effective market economy so as to realize innovation and technological development [5].

In the meso perspective, Yamamura et. al., (2005) described the practice path from imitation innovation to independent innovation in Japan's motorcycle industry [6]. Hao (2007) put forward that ecologization and clustering of technological innovation in industries was an effective way to promote technology level of industries, enhance competitiveness and achieve sustainable development [7]. Dijk and Yarime (2010) expounded the path dependence of hybrid electric vehicle industry from the aspects of demand, supply and supervision [8]. Wang and $\mathrm{Xu}$ (2012) proposed paths to realize the unlocking of industrial technology innovation from four aspects: enhancing participants' cognitive ability, improving external environment, implementing interest induction and carrying out external shocks [9].

In the micro perspective, Wang and $\mathrm{Pu}$ (2005) considered that different company management patterns would lead to different technology innovation paths [10]. Li et. al., (2010) considered that strategic alliances in contractual equity or joint modes would result in the technology innovation paths with extensibility, breakthrough and creativity [11]. Thrane and Blaabjerg (2010), with the example of medical equipment companies in Northern Europe, analyzed the path creation and path dependency in product innovation and service innovation [12]. McAdam and Moffett (2010) analyzed how the paths of innovation leadership ability, people and culture, total quality, and the degree of knowledge and information of small and medium-sized enterprises affect the innovation practice by applying the structural equation model [13]. 
Research on influencing factors of innovation path is mainly focused on innovation ways and modes. Zeng and Wan (2000) argued that main influencing factors of innovation mode selection included actual strength of an enterprise, technical conditions, industry conditions, and macro-environment of a nation, etc., [14]. Bayona and GarciaMarco (2001) argued that the most important influencing factor of enterprises' cooperative innovation in research and development was the degree of their technical complementarities, namely the strength of enterprises' absorbing ability [15]. Yasuda et. al., (2005) studied Japanese manufacturing enterprises and found that enterprise size and age had definite impact on the innovation behavior modes of growing enterprises [16]. Kirner et. al., (2009) considered that turnover of new products, product related services, labor productivity and production cycle had effects on the choice of innovation modes of companies with low, medium and high technology [17]. Müller-Seitz and Reger (2009) argued that external influencing factors of the open innovation mode mainly included policy environment of a country and public service platform [18]. Lee et. al., (2010) illustrated technology purchase and strategic alliance of small and medium-sized enterprises under the open innovation mode [19]. He thought that the influencing factors promoting its development included internal human resources within the market and the company, uncertainty of the market, research and development planning and management abilities, technical information access, and liquidity risks, etc., Tan (2011) indicated that the selection of an independent innovation mode had significant correlation with innovation consciousness, input capability of innovation resources, innovation environment, innovation cost, innovation management ability, innovation risks, and innovation subject characteristics etc.,. by using structural equation model [20]. Wang et. al., (2012) took environment variables, construction of resource sharing channel and innovation resource requirements as influencing factors of resource sharing under open innovation mode [21]. Long et. al., (2014) considered that human resources, innovation information sources and enterprise size would affect the way of technological innovation [22].

As to the niche ecostate-ecorole theory, a branch theory of niche, Bakker et. al., (2013) considered that niche is an important theory to study competitiveness between species, species' adaptability to environment, diversity and stability of the ecological system etc., [23]. Hutchinson (1957) defined niche as a total of resource utilization and environment adaptability of a biological unit in the ecosystem, namely the collection of a biological unit's selection range of resources and environment [24]. Yu and He (2007) constructed land resource optimal allocation model based on the niche ecostate-ecorole theory [25]. Chinese scholar Zhu (1997) argued that a niche covered both ecostate and ecorole of a biological unit, which meant that a biological unit of nature or society had two attributes: ecostate and ecorole [26]. Ecostate was an accumulative result of its growth and development, learning, social and economic development, and interaction with the environment in the past. Ecorole referred to the real abilities of a biologic unit in influencing or manipulating the environment. On the basis of these connotations, in recent years, Chinese scholars have applied the niche ecostate-ecorole theory to the field of economic management. Wan (2004) constructed a niche evaluation indicator system for enterprises from the aspects of viability, developing ability, competitiveness based on niche ecostate-ecorole attributes [27]. Yan (2007) constructed an evaluation indicator system of enterprise niche from the two aspects of ecostate and ecorole, and he also constructed an evaluation model of ecostate and ecorole for enterprise niche, effectively reflecting potential competitiveness and viability of an enterprise [28].

In conclusion, domestic and foreign scholars have studied technological innovation path from macro, meso and micro perspectives, but most of them took the macro (nation) or the micro (enterprise) as their research objects, and few took the meso (industry) as their research object. Meanwhile, the study on influencing factors of innovation path was scattered and scarce in recent years, and the research on influencing factors of green 
process innovation path was very rare. Research on the niche ecostate-ecorole theory, a young theoretical branch of niche, has been very deficient; its application to technical and economic management field is especially scarce. Under this background, this paper tries to utilize the niche ecostate-ecorole theory to explore and determine the influencing factors of green process innovation path of Chinese manufacturing. This study will strengthen the research range of technological innovation path in the meso level, enrich and improve the research content of influencing factors of innovation path, and broaden the application scope of niche ecostate-ecorole theory so as to provide scientific basis and theoretical support for the development of green process innovation in Chinese manufacturing industry.

\section{Conceptual Model and Research Hypotheses}

Green process innovation of manufacturing is a complex giant system [29]. As a biological unit in the economic society, it also possesses the attributes of ecostate and ecorole. Green process innovation path is a comprehensive and complex scientific issue, mainly influenced by the accumulation of past innovation, the current state of innovation, and the planning of future innovation development. The above three aspects can be summarized into the ecostate attribute of green process innovation, the ecostate and ecorole interface attribute of green process innovation, as well as the ecorole attribute of green process innovation. Therefore, according to the niche ecostate-ecorole theory, this paper is to explore the influencing factors of green process innovation path of manufacturing from the above three aspects.

\subsection{The Ecostate Attribute of Green Process Innovation}

According to Zhu's (1997) definition of the niche ecostate attribute, this paper defines the ecostate attribute of green process innovation as a result of interaction between green process innovation and environment during its past growth and learning as well as the social and economic development [26]. It reflects the accumulation of personnel and funds in green process innovation, provides support and input for green process innovation, and acts as the foundation for path design and selection. Based on foreign scholars' achievements about the research on accumulation conditions of past innovation activities [30,31], this paper determines that factors representing the ecostate attribute of green process innovation include personnel and funds of science and technology activities, and technical acquisition and renovation. This paper uses R\&D personnel to refer to the personnel of science and technology activities. Internal expense of R\&D funds is selected to indicate the funds of science and technology activities, fund expense of technology introduction is used to indicate technology acquisition, and fund expense of technical reconstruction to is used to indicate technical renovation.

Research and development (R\&D) is an important source of green process innovation. Green et. al., (1994) considered that the inflow of new technical personnel and R\&D training expenses could promote the green process innovation of a company, and the $R \& D$ personnel as well as the internal expense of $R \& D$ fund directly affected the process and result of green process innovation [32]. So the number of R\&D personnel and internal expense of $R \& D$ fund can be considered as essential factors when designing and selecting green process innovation path of manufacturing, and they are the power of continuous manufacturing innovation.

Another basic premise of green process innovation and development is the acquisition of new technology or the ability to transform the introduced new technology. Technology introduction and technical renovation are main factors reflecting the technological innovation content [33]. Technical acquisition and renovation have direct influence on the design and selection of innovation path. Fund expense of technical introduction refers to the cost of purchasing overseas manufacturing technologies, including product design, 
process flow, drawings and equipment. Technical renovation expense refers to the cost spent on technical renovation of manufacturing. Technical renovation applies scientific and technological achievements to different fields, realizes expanded reproduction with advanced techniques so as to optimize the green process innovation path of manufacturing. Based on the above statement, this paper puts forward the following hypotheses:

H1: The ecostate attribute of green process innovation has a positive effect on green process innovation path of manufacturing.

H1-1: The number of R\&D personnel has a positive effect on green process innovation path of manufacturing.

H1-2: The internal expense of $R \& D$ fund has a positive effect on green process innovation path of manufacturing.

H1-3: The fund expense of technology introduction has a positive effect on green process path of manufacturing.

H1-4: The fund of technical renovation has a positive effect on green process innovation path of manufacturing.

\subsection{The Ecostate and Ecorole Interface Attribute of Green Process Innovation}

This paper considers that the ecostate and ecorole interface attribute of green process innovation is a mutual coordination between the internal components of manufacturing in green process innovation activities, which reflects manufacturing's identification, acquisition, configuration and integration of its possessed internal and external resources. Active improvement of this attribute will strengthen the integrated management of green process innovation, and enhance the efficiency of resource utilization. The matching situation between existing resources and the overall effect of green process innovation path of manufacturing has its influence; if the match is good, the path will be valid; otherwise it will be invalid. During the resource integration and management of technological innovation, the productivity rate, external fund support and funding risk control in the process of research and development can have relative strong reflection of mutual coordination between internal factors of green process innovation of manufacturing [34-36]. So this paper considers that $R \& D$ production, $R \& D$ subsidy and risk management control can be used to characterize the ecostate and ecorole interface attribute of green process innovation. This paper uses labor productivity (new product output/R\&D personnel in total) to express $R \& D$ production, tax exemption and reduction for encouraging technology development to express R\&D subsidy, and current asset turnover ratio to express risk management and control.

Green K (1994), Kemp et. al., (1992) and Tan X (2010) thought that control of uncertain economic consequences and government's policy support were of great importance to $R \& D$ and innovation of clean technology [32,37,38]. $R \& D$ producing capacity, government financial support for $\mathrm{R} \& \mathrm{D}$ project and risk control in the production process are necessary for manufacturing to maintain its leading position in green process and carry out sustainable green process innovation. These factors are guarantee for green process innovation and further affect the design, selection and implementation of green process innovation path of manufacturing. Labor productivity refers to the use value or efficiency of specific labor production. It is an important indicator to monitor and measure manufacturing process innovation [39]. It is also an important indicator to assess the level of manufacturing production. The increase of labor production efficiency shows the improvement of worker's adaptability to new process, which will be more beneficial for the implementation of green process innovation path. The green process innovation path is also influenced by national policies. The tax exemption and reduction to encourage technology development reflects the nation's supporting degree of innovative technology. Current asset turnover ratio reflects the turnover speed of current assets in manufacturing, which is an important factor to analyze asset quality in risk management control. The 
higher the current asset turnover ratio is, the lower the fund risk of manufacturing will be, and the stronger guarantee will be provided to the green process innovation path of manufacturing. According to the above description, this paper puts forward the following hypotheses:

H2: The ecostate and ecorole interface attribute of green process innovation has a positive effect on green process innovation path of manufacturing.

H2-1: The labor productivity has a positive effect on green process innovation path of manufacturing.

H2-2: The tax exemption and reduction to encourage technology development has a positive effect on green technology innovation path of manufacturing.

H2-3: The current assets turnover ratio has a positive effect on green process innovation path of manufacturing.

\subsection{The Ecorole Attribute of Green Process Innovation}

This paper thinks that the ecorole attribute of green process innovation has actual influence and manipulation of green process innovation activities on environment, and it also shows material, energy and information exchange and conversion with environment. Good transformation of green process innovation achievements characterizes relatively high ecorole attribute, which will improve maneuverability of the green process innovation path, promote development of green process innovation, and provide support for manufacturing to obtain sustainable competitive advantages. According to domestic and foreign scholars' illustration about the indicators of technological innovation transformation $[40,41]$, this paper considers that green process innovation transformation is directly reflected in patent and output value of new products, and indirectly reflected in the feedback of environmental and social situation, and both of them will affect the design, selection and implementation of innovation path. Indicators representing the ecorole attribute of green process innovation contain number of invention patents, output value of new products, and degree of environmental impact and rate of social contribution. Among which, the number of invention patents is represented by the proportion of invention patents (number of invention patents/number of patent applications). The output value of new product is represented by the proportion of output value of new product (new product output/gross industrial output value). This paper selects waste emissions of process and number of waste gas treatment facilities to represent the degree of environmental influence. The rate of social contribution is represented by asset contribution rate.

The proportion of invention patents mainly reflects the output quality of technical achievements in the green process innovation of manufacturing. Blazsek et. al., (2010) suggested that patents' higher requirements for output quality and service will form entry barriers to competitors, and increase their production cost so as to maintain the sustainable competitive advantage of manufacturing [42]. The quality of patent output depends on optimal allocation of a variety of resources, and different resource allocation will form different green process innovation path. The proportion of output value of new product refers to the proportion accounted for the output value of a new product, which is used to reflect process innovation output and its direct contribution to economic growth; increase in output value shows that the production process of a new product meets the market needs, and thus it will provide strong support for path design, selection and implementation. Bi et. al., (2002) considered that green process innovation covers two aspects: clean technology that can reduce pollution during production and end treatment technology that reduces wastes emission [43]. Large amount of waste water, waste residue and waste gas arising during product processing does not meet the requirements of clean production, so, at this point, green process innovation is particularly important. Therefore, process waste gas emission and number of waste gas treatment facilities can better reflect the impact of green process innovation of manufacturing on environment. 
Process waste gas emission refers to the total gas containing pollutants discharged into the air from fuel burning during process production of manufacturing. Waste gas emission will cause damage to the environment, and it goes against the implementation effect of green process innovation path. Waste gas treatment facilities will reduce environmental pollution caused by manufacturing, promote the transformation from traditional process to green process, and enhance the development and implementation of green process innovation path, so the number of waste gas treatment facilities indicates the attention degree of manufacturing about green process innovation. Asset contribution rate reflects the profitability of all manufacturing assets, which is the best indicator to evaluate and assess the social contribution of manufacturing. Asset profitability directly affects the motive of manufacturing to realize the evolution from traditional process innovation to green process innovation with full power. On the above bases, this paper puts forward the following hypotheses:

H3: The ecorole attribute of green process innovation has a positive effect on green process innovation path of manufacturing.

H3-1: The proportion of invention patents has a positive effect on green process innovation path of manufacturing;

H3-2: The proportion of output value of new product has a positive effect on green process innovation path of manufacturing;

H3-3: The waste gas emission of production process has a negative effect on green process innovation path of manufacturing;

H3-4: The number of waste gas treatment facilities has a positive effect on green process innovation path of manufacturing;

H3-5: The rate of asset contribution has a positive effect on green process innovation path of manufacturing.

Based on the above analyses, a hypothetical logic concept model is constructed as shown in the following Figure 1:

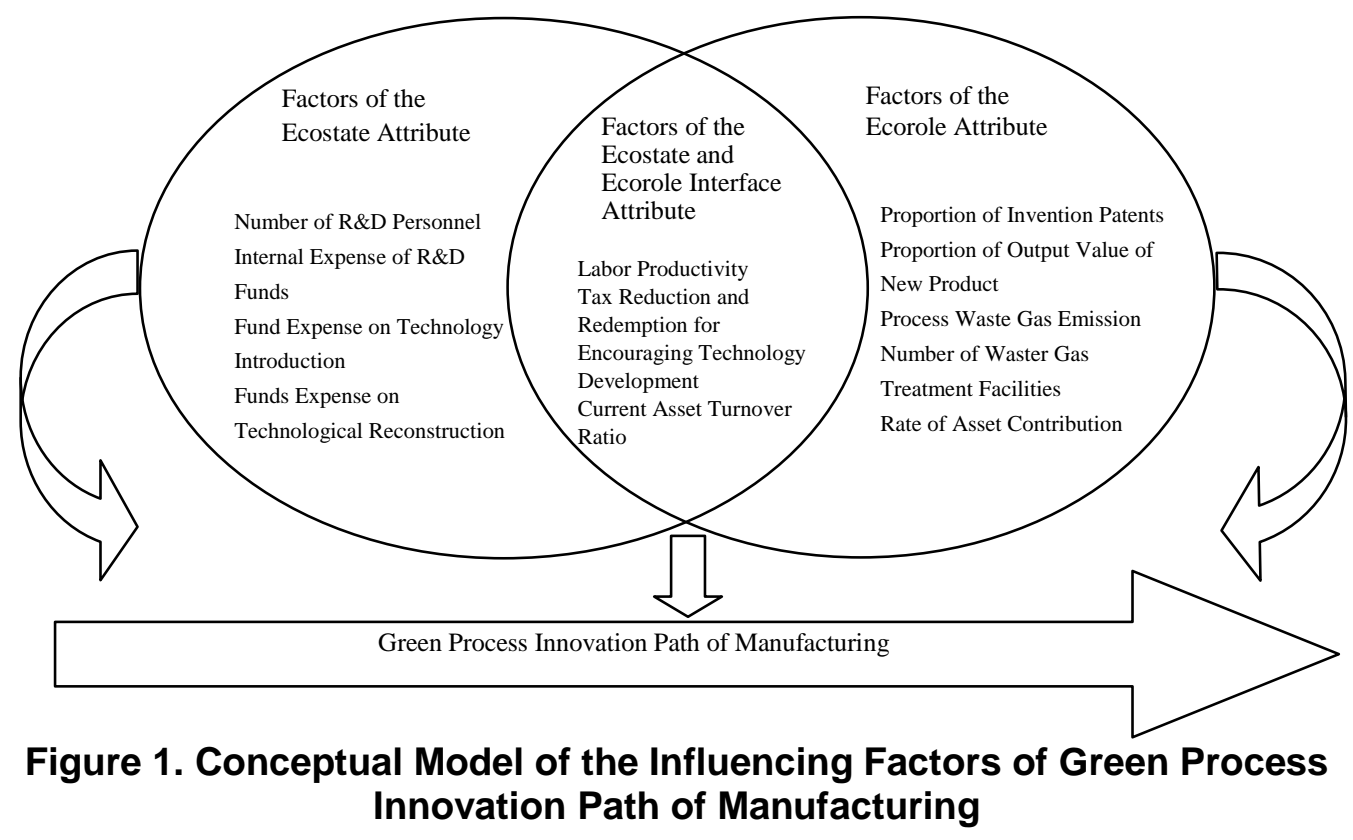

\section{Empirical Analysis}

\subsection{Selection of Samples and Data}

This research mainly studies 203 samples covering 29 manufacturing industries in China from 2006 to 2012. Data of the samples are sufficient in amount to meet the 
requirements of structural equation model. During this period, China's manufacturing has experienced global financial storm, but the data has no serious fluctuation, so it has very small impact on this research. The data mainly come from Statistics Yearbook on Science and Technology Activities of Industrial Enterprises, and China Statistical Yearbook on Environment, China Industry Economy Statistical Yearbook, China Statistical Yearbook on Science and Technology, and China Industry Statistical Yearbook. Since some data necessary for this study cannot be directly obtained from the statistical yearbooks, we get them by calculation and deduction. Before data verification, we first fill the missing values of some certain samples. The basic approaches for SPSS to deal with missing values include case deletion, regression substitution and mean substitution. But case deletion is to obtain complete data by reducing the sample size, resulting in large waste in resources and discarding large amount of information hiding in the deleted cases. Regression substitution opts to ignore random errors, underestimate standard deviation and other measurements with unknown property. So this paper selects the average value of a certain variable in different cases to fill in the missing value. In order to avoid heteroskedasticity during the modeling process and make the data have better features, this paper then treats all the data with logarithm.

\subsection{Model of Empirical Analysis}

4.2.1. Validity Analysis: We first implement validity analysis on various indicators of the factors influencing green process innovation path. The results are shown in Table 1.

Table 1. Tests of KMO and Bartlett

\begin{tabular}{l|l|l}
\hline \multicolumn{3}{c}{ Examination of KMO and Bartlett } \\
\hline \multirow{2}{*}{ KMO Statistics for Partial Correlation between Variables } & .819 \\
\hline \multirow{3}{*}{ Bartlett's Sphericity Test } & Approx. Chi-Square & 2403.058 \\
\cline { 2 - 3 } & df & 91 \\
\cline { 2 - 3 } & Sig. & .000 \\
\hline
\end{tabular}

Table 1 shows that the KMO value of the influencing factors is 0.819 , which is bigger than the standard value of 0.5 , and the P value of Bartlett's sphericity test is 0.000 , which is smaller than the standard value of 0.001 . So, it verifies that the correlation between each indicator of the influencing factors is relatively strong, and we can handle these indicators with factor analysis.

4.2.2. Model Fitting Analysis: This paper builds the model on the basis of structural equation model, and applies the software of SPSS21.0 and AMOS21.0 to data fitting to get fitting indicators of the initial model, and finds that the fitting between the initial model and the data is not good, which is far behind good fitting indicator, so the initial model needs to be modified. This paper mainly adopts the modified indicator (MI) provided by AMOS21.0 to determine the reason of poor adaptation degree between theoretical model and empirical data. Fitting of the theoretical model constructed in this paper is shown in Table 2.

Table 2. Fitting of the Structural Equation Model after Modification

\begin{tabular}{l|l|l|l}
\hline \multirow{2}{*}{ Absolute Fit Indices } & Fitting Indicator & Fitting Value & Ideal Value for Reference \\
\cline { 2 - 4 } & Degree of Freedom $(\mathrm{df})$ & 31 & \\
\cline { 2 - 4 } & $\mathrm{x} 2$ & 50.992 & \\
\cline { 2 - 4 } & NC(x2/df) & 1.645 & $1<\mathrm{NC}<3$ \\
\cline { 2 - 4 } & GFI & 0.961 & $>0.90$ \\
\hline \multirow{2}{*}{ Relative Fit Indices } & NFI & 0.068 & $>0.90$ \\
\cline { 2 - 4 } & IFI & 0.971 & $>0.90$ \\
\hline
\end{tabular}




\begin{tabular}{l|l|l|l}
\hline & CFI & 0.988 & $>0.90$ \\
\hline
\end{tabular}

Table 2, shows that $\mathrm{x} 2 / \mathrm{df}$ is 1.645 , indicating that complex degree of the model design is reasonable. According to the reasonable range suggested by Browne and Cudeck (1993) [44], the 0.961 of GFI and the 0.068 of RMSEA is within a reasonable range. The 0.971 of NFI, the $0.989 \mathrm{of}$ IFI, and the 0.988 of CFI conform to the ideal range of model fitting proposed by Bentler and Bonett (1980) [45], indicating that the model fit is reasonable. So, the structural relationship designed in this paper can reflect the variables' influence on green process innovation path of manufacturing.

4.2.3. The Path Graph and Parameter Estimation after Modification: Based on the requirements of theoretical model, this paper constructs a hypothetical model of secondorder confirmatory factor analysis, namely the structural equation model diagram of influencing factors of green process innovation path of manufacturing, as shown in Figure 2.

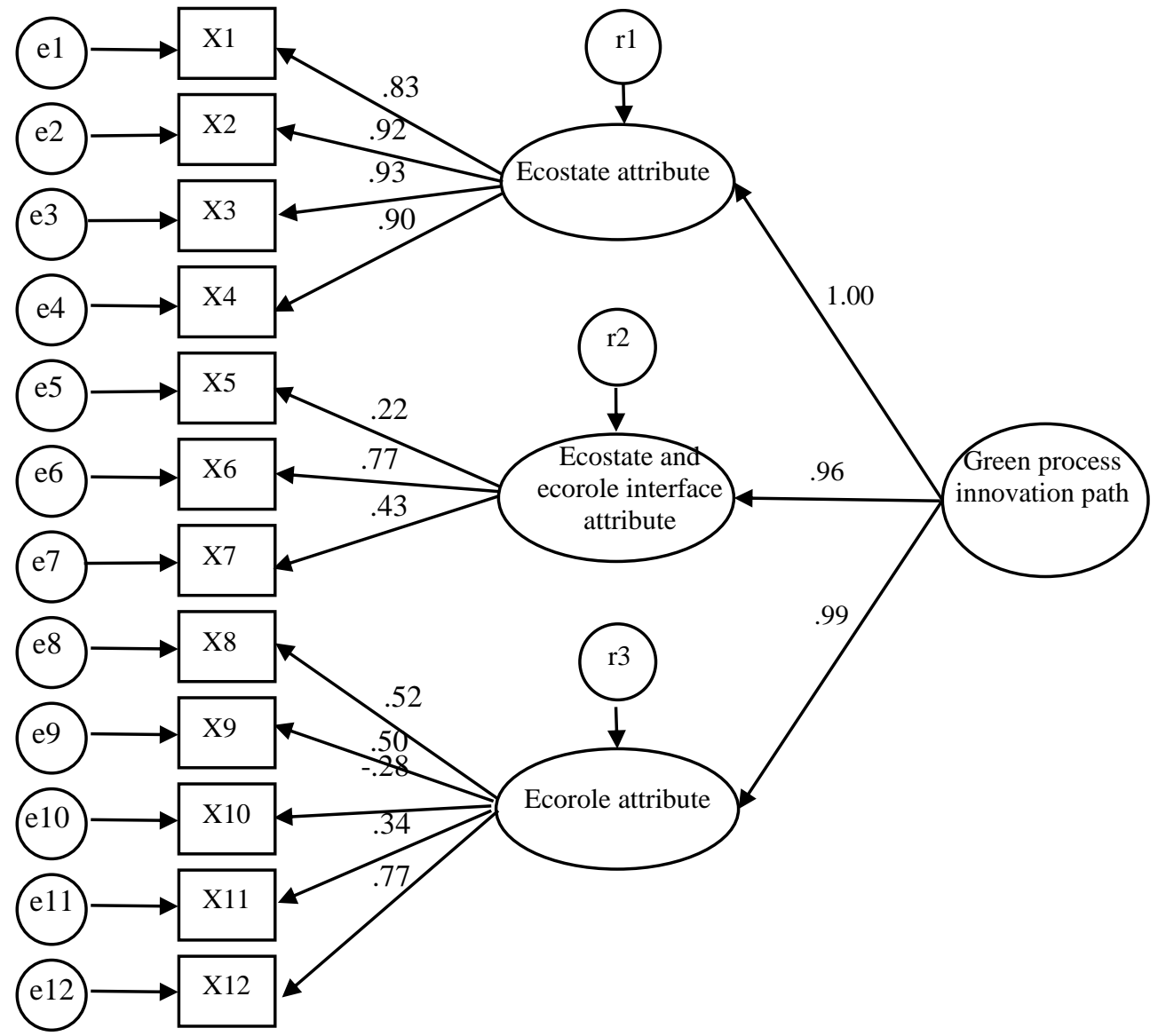

Figure 2. Structural Equation Model of Influencing Factors of Green Process Innovation of Manufacturing

This figure can directly tell the relationship between latent variables, as well as the observation indicators of each latent variable. Through this figure, we can directly observe how the three latent variables: the ecostate attribute, the attribute of ecostate and ecorole interface, and the ecorole attribute of green process innovation affect green process innovation path of manufacturing and each coefficient. When a latent variable cannot be completely and fully explained by the observed variables, error terms or residual terms of model estimation will appear. In which, e1, e2, ..., e12 are error terms of observed variables (measurement indicator) and there is no correlation between them; $r$, 
$\mathrm{r} 2, \mathrm{r} 3$ are error terms of latent variables (first-order factors) and there is no correlation between ei and $\mathrm{rj} ; \mathrm{x} 1, \ldots, \mathrm{x} 4$ respectively stand for the number of $\mathrm{R} \& \mathrm{D}$ personnel, the internal fund of $\mathrm{R} \& \mathrm{D}$, the fund expenses on technology introduction, and the fund expenses on technical reconstruction, labor productivity, tax exemption and reduction to encourage technology development, current assets turnover ratio of the attribute factors of ecostate and ecorole interface, and number of invention patents, proportion of new product output value, waste gas emission of production process, number of waste gas treatment facilities, and rate of assets contribution of the ecorole attribute factors.

This paper verifies related hypotheses according to fitting results of the correction model, as shown in Table 3 . We adopt the nonstandardized regression coefficient by using maximum likelihood estimation. When constructing the model, we set the fixed parameter " 1 " for the nonstandardized regression coefficient of he ecostate attribute of "green process innovation <--- the green process innovation path of manufacturing, the X1 <--the ecostate attribute of green process innovation, X5 <--- the attribute of ecostate and ecorole interface of green process innovation, X8 <---the ecorole attribute of green process innovation", so these three parameters do not need to undergo path the test of coefficient significance and values of the standard error (S.E.), critical ratio (C.R.) and significant $\mathrm{P}$ value are blank. In the model, statistical results of the regression coefficient between latent variables (path coefficient) and the regression coefficient between latent variables and measurements (load coefficient) show that $\mid$ C. R. $\mid>1.96$, and the P values are less than 0.05 , which indicates that all parameter estimates have relatively high significance in the model, so it can be concluded that all 15 hypotheses are being supported.

Table 3. Model Parameter Estimation after Modification

\begin{tabular}{|c|c|c|c|c|c|c|c|}
\hline Hypotheses & Effect Path & $\begin{array}{l}\text { Standardized } \\
\text { Path coefficient }\end{array}$ & Estimate & S.E. & C.R. & $\mathrm{P}$ & $\begin{array}{l}\text { Test } \\
\text { Result }\end{array}$ \\
\hline H1 & $\begin{array}{l}\text { Ecostate Attribute<--- } \\
\text { Innovation Path }\end{array}$ & 1.00 & 1.0 & & & & Supported \\
\hline $\mathrm{H} 2$ & $\begin{array}{l}\text { Attirbute of Ecostate and } \\
\text { Ecorole Interface }<--- \\
\text { Innovation Path }\end{array}$ & .96 & .090 & .027 & 3.309 & $* * *$ & Supported \\
\hline $\mathrm{H} 3$ & $\begin{array}{l}\text { Ecorole Attribute }<--- \\
\text { Innovation Path }\end{array}$ & .99 & .267 & .034 & 7.770 & $* * *$ & Supported \\
\hline H1-1 & $\mathrm{X} 1<---$ Ecostate Attribute & .83 & 1.00 & & & & Supported \\
\hline $\mathrm{H} 1-2$ & $\mathrm{X} 2<---$ Ecostate Attribute & .92 & 1.501 & .082 & 18.9262 & $* * *$ & Supported \\
\hline $\mathrm{H} 1-3$ & $\mathrm{X} 3<---$ Ecostate Attribute & .93 & 1.382 & .078 & 17.626 & $* * *$ & Supported \\
\hline H1-4 & $\mathrm{X} 4<---$ Ecostate Attribute & .90 & 1.285 & .068 & 18.851 & $* * *$ & Supported \\
\hline $\mathrm{H} 2-1$ & $\begin{array}{l}\text { X5<--- Attirbute of Ecostate } \\
\text { and Ecorole Interface }\end{array}$ & .22 & 1.00 & & & & Supported \\
\hline $\mathrm{H} 2-2$ & $\begin{array}{l}\text { X6 } 6<--- \text { Attirbute of Ecostate } \\
\text { and Ecorole Interface }\end{array}$ & .77 & 13.792 & 4.207 & 3.278 & .001 & Supported \\
\hline $\mathrm{H} 2-3$ & $\begin{array}{l}\mathrm{X} 7<--- \text { Attirbute of Ecostate } \\
\text { and Ecorole Interface }\end{array}$ & .43 & 5.466 & 1.745 & 3.132 & .002 & Supported \\
\hline $\mathrm{H} 3-1$ & X8<--- Ecorole Attribute & .52 & 1.00 & & & & Supported \\
\hline $\mathrm{H} 3-2$ & X9<--- Ecorole Attribute & .50 & 1.002 & .174 & 5.758 & $* * *$ & Supported \\
\hline H3-3 & X10<--- Ecorole Attribute & -.28 & -.363 & .110 & -3.286 & .001 & Supported \\
\hline $\mathrm{H} 3-4$ & X11<--- Ecorole Attribute & .34 & 1.025 & .164 & 6.258 & $* * *$ & Supported \\
\hline H3-5 & X12<--- Ecorole Attribute & .77 & 4.679 & .550 & 8.513 & $* * *$ & Supported \\
\hline
\end{tabular}

\subsection{Result Analyses}

Analyzing from the latent variable of ecostate attribute of green process innovation, we can see that the ecostate attribute of green process innovation has a significant positive influence on green process innovation path of manufacturing and its influencing 
coefficient reaches 1 , which means that personnel and fund of the ecostate attribute have relatively important effect on innovation path. Load factors between the number of R\&D personnel, internal expenses of R\&D fund, fund expenses on technology introduction, fund expenses on technical reconstruction and the ecostate attribute of green process innovation are $0.83,0.92,0.93,0.83$, so they obviously have strong influence on the ecostate attribute. This suggests that investment of personnel and funds is comparatively important during green process innovation, which is a premise of green process innovation of manufacturing. Since fund expenses on technology introduction is the highest of all the path coefficients, it means that many techniques of Chinese manufacturing are acquired from introduction, so most part of Chinese green process innovation of manufacturing is at the stage of imitation innovation. Based on the above analyses, it can be concluded that Chinese manufacturing shall increase investment in personnel and funds, put emphases on investment of technology introduction and reconstruction, and, at the same time, strengthen the ability of independent innovation so as to improve the capacity of path design, selection and implementation.

Analyzing from the latent variable of the ecostate and ecorole interface attribute, we find that the ecostate and ecorole interface attribute of green process innovation also has obvious effects on green process innovation path of manufacturing and the influence coefficient is 0.96 , but its effects are lower than those of the ecostate attribute and ecorole attribute of the green process innovation, which suggests that investment on the level of the ecostate and ecorole interface attribute of green process innovation is not strong enough. The influencing coefficients of labor productivity, tax exemption and reduction to encourage technology development, and current assets turnover are $0.22,0.77$, and 0.43 , which indicates that labor productivity and current assets turnover rate reduce the influencing coefficients of the ecostate and ecorole interface attribute of green process innovation of manufacturing as a whole. In recent years, China has given more significant support to green process innovation, so manufacturing itself shall improve the utilization rate of labor production and encourage R\&D personnel to work with high efficiency. Manufacturing shall improve supervision and management on asset risk control, using effectively and promoting its flow, such as lowering cost, transferring temporarily idle funds to short-term investments for benefits, improving comprehensive use efficiency of liquid assets, so as to ensure the successful implementation of green process innovation path of manufacturing.

Analyzing from the ecorole attribute, we find that the ecorole attribute of green process innovation has a great effect on green process innovation path of manufacturing and its influencing coefficient is 0.99 , so the influencing power is very strong. The influencing coefficients of the five indicators: the proportion of invention patents, the proportion of output value of new product, the waste gas emission of production process, the number of waste gas treatment facilities and the rate of assets contribution, are respectively 0.52, $0.50,-0.28,0.34$, and 0.77 . Among them, the rate of assets contribution has the highest path coefficient on the ecorole attribute of green process innovation, which means that the asset profitability of manufacturing directly affects the ecorole attribute of the green process innovation, and then affects the green process innovation path of manufacturing. The proportion of invention patents and the proportion of output value of new product have very close influencing degree on the ecorole attribute of green process innovation, and their influencing coefficients are in a moderate level. The waste gas emission of production process and the number of waste gas treatment facilities are very low in coefficient, which shows that they do not influence the green process innovation path in a relatively good way. These two indicators reflect the degree of environmental protection during the process innovation, while one of the purposes of green innovation production is to reduce the pollution resulting from process manufacturing so as to achieve sustainable development of production, so this requires the manufacturing to reduce waste emissions, decrease negative impact of process waste on innovation path, and increase the 
number of waste gas treatment facilities. The manufacturing shall also pay close attention to the assessment of these two indicators, and then promote the transformation from traditional process to green process and advance the development and implementation of green process innovation path.

\section{Conclusion and Recommendation}

Based on the existing research results, this paper analyses the influencing factors of green process innovation path and determines the influencing degree of each factor on the green process innovation path by using the niche ecostate-ecorole theory and structural equation model. It is found that the ecostate attribute, the ecostate and ecorole interface attribute, and the ecorole attribute of green process innovation have significant positive influences on the green process innovation path. This conclusion has positive inspiration and reference for further deepening the research on green process innovation path and instructs the activities of green process innovation of manufacturing.

First of all, the investment in personnel and funds of green process innovation of manufacturing should be increased. Strategic vision and risk assuming ability are necessary. Simple technology introduction or imitation innovation of technology transformation can also help make some profits and develop to some degree, but they cannot ensure manufacturing to obtain sustainable competitive advantages. Therefore, manufacturing shall have more core technologies of independent research and development, optimize the industrial structure, accelerate industrial upgrading, so as to optimize the process innovation path of manufacturing, and achieve sustainable development in market competition.

Secondly, the manufacturing shall improve its ability in R\&D and production, and reasonably allocate the $R \& D$ subsidy from government. In order to encourage $R \& D$ personnel to innovate and produce with high efficiency, it is necessary to improve the incentives of green process innovation, so the R\&D personnel shall be allowed to have technology investment shares with their green process innovation achievements and enjoy the benefits of dividends. In this way, the R\&D personnel shall be encouraged to carry out $R \& D$ work efficiently and improve production capacity. Besides, the manufacturing shall also enhance reasonable allocation of government $R \& D$ subsidies, fully exert leverage of funds, improve output rate of patents, and maximize effectiveness and efficiency of government funds so as to provide powerful guarantee for the design, selection and implementation of green process innovation path of manufacturing.

Finally, the manufacturing shall emphasize patent output and actively carry out green innovation to reduce environmental pollution. In order to make successful patent output, manufacturing must plan the patent acquisition and protection with purpose, which can effectively improve the proportion of patents. The most important thing during the process input and transformation is to implement green innovation so as to reduce environmental pollution. Besides reducing waste emissions and increasing the number of waste treatment facilities, manufacturing shall also reduce sewage volume with "endtreatment" mode, and implement green process innovation in the intermediate links of production. The phenomenon of "curing the symptoms, not the disease" shall not emerge and we shall actively promote the effective implementation of green process innovation path of manufacturing.

\section{Acknowledgments}

The study is supported by National Natural Science Foundation of China (NFSC) under Grant No. 71203048, National Undergraduate Training Programs for Innovation and Entrepreneurship under Grant No. 201510214061, Heilongjiang Natural Science Foundation under Grant No. QC2016098 and Heilongjiang Social Science Planning Fund Program under Grant No. 16GLB02. 


\section{References}

[1] H. N. Tian and K. X. Bi, "The evolution of Green process innovation system of manufacturing based on self-organization", Journal of scientific research management, vol. 33, no. 8, (2012), pp. 18-25.

[2] D. C. Mowery and N. Rosenberg. "Paths of Innovation: Technological Change in Twentieth-Century America", Journal of Economic Literature, vol. 37, no. 2, (1999), pp. 698-699.

[3] S. M. Chen, "The European standardization externalities have influence on technology innovation path of China's export enterprises", Journal of China soft science, no. 1, (2007), pp. 90-100.

[4] L. P. Fu and Y. J. Gu, "From the introduction to the technology innovation: the inspiration and reference of South Korea's hyundai motor technology innovation path", Journal of science and management research, vol. 26, no. 1, (2008), pp. 117-120.

[5] E. A. Klochikhin, "Russia's innovation policy: Stubborn path-dependencies and new approaches", Research Policy, vol. 41, no. 6, (2012), pp. 1620-1630.

[6] E. Yamamura, T. Sonobe and K. Otsuka, "Time path in innovation imitation and growth: the case of the motorcycle industry in postwar Japan”, Journal of Evolutionary Economics, vol. 15, no. 2, (2005), pp. 169-186.

[7] D. Q. Hao, Z. F. Wang and X. C. Guo, "The selection of technology innovation path of coal industry of Nei Meng-gu", Journal of Science management research, vol. 25, no. 1, (2007), pp. 16-19.

[8] M. Dijk and M. Yarime, "The emergence of hybrid-electric cars: Innovation path creation through coevolution of supply and demand", Technological Forecasting \& Social Change, vol. 77, no. 8, (2010), pp. 1371-1390.

[9] Z. L. Wang and X. D. Xu, "The lock and unlock of technology innovation path", Journal of Science and Science technology management, vol. 33, no. 4, (2012), pp. 60-66.

[10] C. L. Wang and Y. J. Pu, "The corporate governance, the technology innovation path and industry specialization", Journal of management engineering, no. 3, (2012), pp. 10-14.

[11] J. Li, S. J. Yao and F. T. Wu, "The selection of alliance structure and the evolution of technology innovation path", Journal of science and science technology management, no. 3, (2010), pp. 72-76.

[12] S. Thrane, S. Blaabjerg and R. H. Møller, "Innovative path dependence: Making sense of product and service innovation in path dependent innovation processes", Research Policy, vol. 39, no. 7, (2010), pp. 932-944.

[13] R. McAdam, S. Moffett, S, A, Hazlett and M. Shevlin, "Developing a model of innovation implementation for UK SMEs: A path analysis and explanatory case analysis", International Small Business Journal, vol. 28, no. 3, (2010), pp. 195-214.

[14] J. Zeng and J. K. Wan, "The analysis of influencing factors of enterprise technology innovation model", Journal of scientific technological progress and countermeasures, vol. 17, no. 4, (2000), pp. 3-4

[15] C. Bayona, T. Garcia-Marco and E. Huerta, "Firms' motivations for cooperative R\&D: an empirical analysis of Spanish firms", Research Policy, vol. 30, no. 8, (2001), pp. 1289-1307.

[16] T. Yasuda, "Firm growth, size, age and behavior in Japanese manufacturing", Small Business Economics, vol. 24, no. 1, (2005), pp. 1-15.

[17] E. Kirner, S. Kinkel and A. Jaeger, "Innovation paths and the innovation performance of low-technology firms-An empirical analysis of German industry", Research Policy, vol. 38, no. 3, (2009), pp. 447-458.

[18] G. Müller-Seitz and G. Reger, "Is open source software living up to its promises? Insights for open innovation management from two open source software-inspired projects", R\&D Management, vol. 39, no. 4, (2009), pp. 372-381.

[19] S. Lee, G. Park, B. Yoon and J. Park, "Open innovation in SMEs-An intermediated network model", Research policy, vol. 39, no. 2, (2010), pp. 290-300.

[20] R. J. Tan, "The empirical research of influencing factors of independent innovation mode and innovation performances of Zhu San-jiao equipment manufacturing", Journal of science and technology management research, no. 22, (2011), pp. 1-6.

[21] H. H. Wang,Z. L. Peng and X. C. Jiang, "The influencing factors of innovation resource sharing with open innovation mode", Journal of scientific research management, vol. 33, no. 3, (2012), pp. 49-55.

[22] Z. H. Long, R. P. Lou and D. F. Yang, "The influencing factors of innovation mode selection", Journal of systems engineering, vol. 32, no. 6, (2014), pp. 85-90.

[23] S. Bakker, H. van Lente and R. Engels, "Competition in a technological niche: the cars of the future", Technology Analysis \& Strategic Management, vol. 24, no. 5, (2012), pp. 421-434.

[24] G. E. Hutchinson, "Concluding remarks: Cold Spring Harbor Symposia on Quantitative Biology", Cold Spring Harbor Laboratory Press, vol. 39, no. 2, (1957), pp. 415-427.

[25] Y. Yu and J. He, "Research on the model of land resource optimal allocation based on land use niche" Geoinformatics 2007, International Society for Optics and Photonics, (2007), 67543H-67543H-9.

[26] C. Q. Zhu, "The niche ecostate-ecorole theory and expand the hypothesis", Journal of ecology, no. 3, (1997), pp. 324-332.

[27] L. L. Wan, "The niche and evaluation method of enterprise", Journal of China soft science, no. 1, (2004), pp. $73-78$.

[28] A. M. Yan, "The research of evaluation indicator and model building of enterprise niche", Journal of science technology progress and countermeasures, vol. 24, no. 7, (2007), pp. 156-160. 
[29] M. Bergfors and T. Lager, "Innovation of process technology: exploring determinants for organizational design", International Journal of Innovation Management, vol. 15, no. 5, (2011), pp. 1113-1140.

[30] D. deS Price, "The science/technology relationship, the craft of experimental science, and policy for the improvement of high technology innovation", Research Policy, vol. 13, no. 1, (1984), pp. 3-20.

[31] J. I. Lewis, "Technology acquisition and innovation in the developing world: wind turbine development in China and India", Studies in comparative international development, vol. 42, no. 3-4, (2007), pp. 208232.

[32] K. Green, A. McMeekin and A. Irwin, "Technological trajectories and R\&D for environmental innovation in UK firms", Futures, vol. 26, no. 10, (1994), pp. 1047-1059.

[33] K. X. Bi and D. H. Sun, "The empirical research of coordinated development of product innovation and process innovation of manufacturing enterprise based on complex system coordination degree model", Journal of China soft science, no. 9, (2010), pp. 156-162.

[34] J. Fagerberg, "Technological progress, structural change and productivity growth: a comparative study", Structural change and economic dynamics, vol. 11, no. 4, (2000), pp. 393-411.

[35] Z. Z. Cheng, Y. L. Wu and Z. Y. Xie, "The relations research of technology innovation ability and the enterprise scale", Journal of technology economy, vol. 27, no. 6, (2008), pp. 27-31.

[36] H. Ni, T. Luan, Y. Cao and D. Finlay, "Can venture capital trigger innovation? New evidence from China”, International Journal of Technology Management, vol. 65, no. 1, (2014), pp. 189-214.

[37] R. Kemp and L. Soete, "The greening of technological progress--An evolutionary perspective", Futures, vol. 24, no. 5, (1992), pp. 437-457.

[38] X. Tan, 2010. "Clean technology R\&D and innovation in emerging countries-Experience from China", Energy Policy, vol. 38, no. 6, (2010), pp. 2916-2926.

[39] M. B. Ayhan, Ö. Ercan, M. E. Aydin and Y. Yong, "A quantitative approach for measuring process innovation: a case study in a manufacturing Company", International Journal of Production Research, vol. 51, no. 11, (2013), pp. 3463-3475.

[40] Y. Lin and H. Z. Zhang, "Main Effect and Experience on Science and Technology Innovation and Transformation of Achievements in Si-chuan Academy of Agricultural Sciences", Management of Agricultural Science and Technology, no. 4, (2008), pp. 022.

[41] H. Shu and Y. Liu, "The analysis of model and timing of technology innovation achievements Standardized", Journal of science and technology management research, no. 17, (2014), pp. 171-177.

[42] S. Blazsek and A. Escribano, "Knowledge spillovers in US patents: A dynamic patent intensity model with secret common innovation factors", Journal of Econometrics, vol. 159, no. 1, (2010), pp.14-32.

[43] K. X. Bi, X. H. Ding and Y. J. Feng, "The review of evaluation present situation and development trend of process innovation of manufacturing small and medium-sized enterprise", Journal of scientific research management, vol. 23, no. 6, (2002), pp. 125-132.

[44] M. W. Browne and R. Cudeck, 1993. "Alternative ways of assessing model fit", Sage Focus Editions, no. 154, (1993), pp. 136-136.

[45] P. M. Bentler and D. G. Bonett, 1980. "Significance tests and goodness of fit in the analysis of covariance structures”, Psychological bulletin, vol. 88, no. 3, (1980), pp. 588.

\section{Authors}

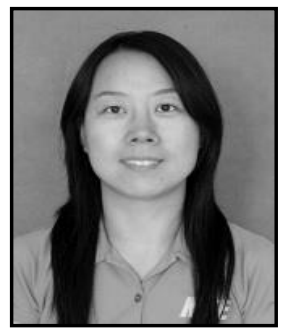

Tian Hongna, received her doctor's degree in management from Northeast Forestry University, China in 2007. She is currently a professor in Harbin University of Science and Technology, PR China. Her current research focuses on technological innovation, industrial innovation and strategic management. 